\title{
Neo-Prussian Politics: Absolutism in the United States Charles Huckelbury
}

Tn 1750, Voltaire accepted an invitation from Frederick the Great to become 1 a permanent resident of the king's court in Berlin. The situation quickly soured, and after frequent acrimonious disputes, the two mutually agreed that the best place for Voltaire would be out of the country. On his way home in 1753, however, he was arrested in Frankfurt on the king's order. In a fit of pique, Frederick had accused Voltaire of making off with some poetry that rightly belonged to the Crown. As king, Frederick had the undisputed power to do whatever he wanted without worrying about political repercussions or Voltaire's civil rights. Confined without legal recourse, all Voltaire could do was petition Frederick to reconsider and wait, his future uncertain and his very life in the balance. Voltaire was subsequently freed when the king acknowledged the spurious nature of the charge and relented.

On May 22, 2002, José Padilla was arrested at O'Hare International Airport in Chicago also while attempting to get back home from a trip abroad. Initially accused of plotting to detonate a radiological weapon, he was designated an enemy combatant by the President and confined to a Navy brig in South Carolina, without either legal representation or an opportunity to review the evidence against him. President Bush claimed that, as Commander-in-Chief, he had the authority to order any citizen of the United States arrested and held indefinitely. Once the original charge was shown to be as illegitimate as that levied against Voltaire by Frederick, the government dropped its allegation and subsequently maintained that Padilla is a member of a terrorist support network and therefore subject to criminal prosecution, a tactic apparently not included in even the Prussian legal repertoire. ${ }^{1}$

José Padilla, a former Chicago gang member, is certainly no Voltaire. George Bush, however, has a disturbing tendency to emulate Frederick II, asserting a unilateral authority, unencumbered by statutory restraint or constitutional limitation, to lock up anyone anywhere in the country, maintain secret prisons overseas, order the kidnapping of foreign nationals from other nations' sovereign soil, and even initiate domestic spying without a warrant on any citizen that he chooses. Such an absolutist approach was common in the $18^{\text {th }}$ century, but most rational people would argue that it has no place in $21^{\text {st }}$ century governance. And yet it flourishes in the United States today. 


\section{Characteristics of Absolutist Governments}

Absolutism is a political system in which there is no legal or moral limit on the government's power. It is, as Jefferson (1787) famously observed, a "government of wolves over sheep". Such a system is generally ruled by a dictator or monarch, but it can also deceptively appear as a democratic creation that grants far-reaching powers to an elected executive. Fundamental to modern absolutist regimes are centralization of power, close control of social groups, and the superficial appearance of popular representation. Although such systems may contain, for example, legislative and judicial branches, the ruler typically operates autonomously, allowing the other branches a sterile existence without any real check on executive power.

To maintain that power, most absolutist governments cultivate symbiotic relationships with the police and military, often establishing covert law enforcement agencies to monitor and, when necessary, suppress dissent. Although this concentration of unchecked power in the executive directly violates democratic principles, absolutist regimes habitually claim that such centralization of power makes the government more flexible and efficient, especially when responding to threats, either external or internal.

Absolutist governments also engage in more subtle forms of control, often infiltrating social groups, such as churches and student organizations, which are subsequently either abolished or co-opted by government operatives. Obviously, this provides the government with maximum control throughout many levels of society and discourages organized dissent, while simultaneously using the surviving organizations for ideological indoctrination in support of its policies.

Religion often plays a role in this indoctrination as well as in the dissemination of the absolutist government's propaganda. Indeed, it is not uncommon for those regimes to maintain close affiliations with churches to promote loyalty within the population. ${ }^{2}$ Thus, any criticism of the executive approaches heresy. As James I put it in his speech before Parliament on March 21, 1609:

Kings are... God's lieutenants upon earth, and sit upon God's throne... they make and unmake their subjects: they have power of raising, and casting down: of life and of death: judges over all their subjects, and in all causes, and yet accountable to none but God only (Encarta Encyclopedia, “James I", 2005). 
A more recent - and infamous - example of religion propping up an absolutist regime is South Africa's former apartheid government that, until the early 1990s, counted among its most loyal supporters the Dutch Reformed Church, which created a theological justification for the repression of the black majority (Encarta Encyclopedia, "Absolutism", 2005).

Historically, absolutist regimes were flagrantly despotic. Most modern versions, however, at least cloak their intentions in the trappings of democracy, as if they genuinely represent the interests of their citizens. (Zimbabwe's Robert Mugabe comes immediately to mind.) They may even hold fraudulent elections in which the outcome is pre-determined because the leaders have already decided the issue. ${ }^{3}$

Absolutism also employs the Big Lie to consolidate power. Prior to the collapse of the USSR, the Kremlin used this tactic to justify governmental repression, claiming that Soviet policies were designed to build a society of equality for the people. The reality, of course, was something entirely different: favouritism extended to a small clique of influential people with ties to the ruling elite and trickle-down leftovers for everyone else. ${ }^{4}$ Those opposed were imprisoned or executed, tactics familiar to students of modern authoritarian regimes.

\section{Absolutist Roots in the United States}

In the United States, the government's preferred tactic for furthering its absolutist goals, either economic or social, has been, and continues to be, the exploitation of its citizens' fears. Nowhere is this more evident than in matters relating to domestic security, whether in the form of alleged threats from al-Qaeda terrorists or, more generally, as a response to homegrown criminal activity. When it comes to the modern politics of fear, the government can usually increase its power by conflating terrorism and street crime, thereby convincing the electorate that massive imprisonment and the surrender of fundamental civil rights is an appropriate price to pay for additional security.

In 1956, to cite a notorious example, J. Edgar Hoover, FBI Director, authorized the first in a long sequence of secret FBI operations under the rubric COINTELPRO. The operation's goal was to disrupt the domestic activities of specific political groups, whose members were exclusively United States citizens (Encarta Encyclopedia, "Federal", 2005). The 
operation expanded during the 1960s to include black nationalist groups, civil rights organizations, socialist organizations, and leftist groups protesting the Vietnam War, anyone, that is, who disagreed with the government's foreign or domestic policies. Disregarding legal constraints on their activities, FBI agents illegally broke into homes and businesses, tapped the phones of citizens, collected and leaked defamatory material, and sent anonymous mailings to promote dissension within a specific group or to create tension between groups (Encarta Encyclopedia, "Federal Bureau of Investigation", 2005).

But the FBI was not the only enforcement arm of the government engaged in domestic skullduggery. The CIA, officially tasked with collecting intelligence overseas, was engaged in a massive, illegal domestic intelligence operation against anti-war protesters and other dissidents during Richard Nixon's presidency. A special unit of CIA operatives collected and maintained files on at least 10,000 American citizens and had obviously read the FBI's primer on civil rights, using illegal break-ins, wiretaps and surreptitious opening of mail to spy on American citizens (Hersh, 1974).

Then, of course, came Watergate and Richard Nixon's subsequent resignation, both of which ostensibly produced changes in attitudes and operational guidelines for both the FBI and CIA. Unfortunately, the reorganization was doomed from the start because of entrenched philosophies at the top, philosophies that continue to promote and support absolutism and its most egregious excesses. ${ }^{5}$

\section{Presidential Claims of Absolutist Authority}

President Bush is perhaps the world's most vigorous exponent of the precautionary principle, which states that where a specific activity threatens serious injury, although the method by which that injury might be inflicted remains unknown, then all reasonable means should be undertaken to regulate or ban the activity. Ideally suited for use by absolutist governments, the precautionary principle always assumes the worst, even when evidence is ephemeral or non-existent, and focuses on the downside of any scenario. Thus were born, for example, the doctrines of preventive, as opposed to preemptive, warfare and indefinite incarceration without trial.

This approach conflicts sharply with an alternative model: the rule of law. Under that more restrictive standard, the state "reserves coercion, 
detention [and] punishment... for those who have been shown, on the basis of sound evidence and fair procedures, to have committed some wrongful act" (Cole, 2006, p.17).

The current administration in the United States, however, can insouciantly employ the precautionary principle because U.S. citizens have become preoccupied with worst-case scenarios and are largely disinclined - or unable - to analyze what the President and his proxies tell them. Indeed, surveys show that people cannot distinguish between a risk of 1:100,000 and 1:1,000,000 (Sunstein, 2005). If a risk is made comprehensible to them, they react to it irrespective of the probabilities involved. Their decisions are heavily influenced by the media, which until recently have been loath to offer the mildest criticism of either the President or his policies. Bush can therefore play on the public's irrationality and the phenomenon of, as Sunstein (2005) describes it, "fear as wildfire". That is, if citizens are unreasonably afraid of some risk, public discussion may communicate that fear to others, instead of exposing the irrationality behind it.

The Bush administration can therefore "justif[y] coercive action whether it takes the form of detention or torture on the basis of speculation... without either the evidence or the fair legal processes that traditionally have been considered necessary before the state resorts to coercion" (Cole, 2006, p. 17). At its most extreme, the result is a de facto permanent state of emergency, justified by the President's self-declared global war on terror.

The muscle behind the government's policies is, of course, the police and the military, increasingly indistinguishable in philosophy, weapons, and tactics. President Bush has shown a troubling inclination to rely on the use of force as his primary tool of both domestic and foreign policy. There is thus created a perceived connection between the existence of peace and the potential use of force, reinforced by presidential rhetoric. Gray (2006) put it trenchantly when he observed that this nexus has become a "permanent feature of human affairs [because] without the ability to use force, peace and by extension civilization are in jeopardy" (p. 8). This sort of extremism in America dates at least to Thomas Jefferson's observations on the French Revolution. In response to criticism of the September Massacres of 1792, in which over 1,400 people were executed, Jefferson said, "The liberty of the whole earth was depending on the issue of this contest... [R]ather than it should have failed, I would have seen half the earth desolated" (Chernow, 2004, p. 432). The confluence of presidential hubris and the government's 
monopoly on the legitimate use of force therefore has grave consequences for the country's citizens.

The President was recently forced to admit, for example, that he had ordered the National Security Agency (NSA) to conduct covert spying missions on American citizens, without warrant and without either judicial or congressional oversight. Attorney General Alberto Gonzalez justified the surveillance by telling a national audience that since the President had the power to lock up indefinitely any citizen he wanted without formal charge, then intercepting electronic communication without a warrant was hardly worth mentioning (National Public Radio, 2006). Bush himself justified such intrusions by invoking the tired shibboleth of "freedom": he is protecting "our freedoms" against the actions of those who hate and would destroy them.

There is no sense here of an intellectual addressing an academic audience on an esoteric point of political philosophy; Bush is speaking directly to the people whose rights he is violating and finding a receptive audience. ${ }^{6}$ Even if they are not sure what the President is saying, his audience gets the scripted impression that "something politically important is being articulated [and] that there really might be something at stake in political terms" (Beplate, 2005, p. 13).

But the President's claims defy logic. It would have been an easy matter for Bush or his designee to obtain the requisite search warrants before undertaking domestic espionage, or even 72 hours after the surveillance had begun. The Foreign Intelligence Surveillance Act (FISA) of 1978 authorizes domestic surveillance for national security purposes, and the judges sitting on the FISA court routinely grant such requests from the government. From its inception in 1978 through June 1983, the FISA court received 1,422 requests for wiretaps and granted all of them.

Bush instead adopted an absolutist approach to domestic policies, ordering surveillance of American citizens simply because he, employing the rationale of the "unitary executive", decided he had the authority to do so. Anyone questioning either the operation or the motives behind it was disloyal by definition, ${ }^{7}$ a tactic that reduces, in Allen's (1895) terms to "that rank form of provincialism which we know as patriotism". Adding to the surreal nature of this episode is the President's relentless claim that he stands above the law regulating the surveillance of American citizens while insisting that the only persons who violated the law and compromised the 
country's security are those responsible for leaking the information about the domestic spying operation.

The President's position, although likely unknown to the President himself, is supported by the French philosopher Jean Bodin (1606) who claimed that the state has supreme power over its citizens and subjects, unrestrained by any law. That philosophy pre-figured Thomas Hobbes (1651), who maintained that a social contract exists between citizens and their sovereign, one that assigns to the monarch, as the ultimate political authority, the right to absolute power over every citizen. Hobbes further argued that the sovereign's actions did not have to be limited by customs or natural law. Since he/she operates without any obligations to the body politic, the sovereign can create and impose laws as necessary to do his/her will. Small wonder that President Bush, along with James 1, equates policy disagreements with sedition.

Bodin and Hobbes are no longer relevant, except as philosophical dinosaurs. The President's absolutist assertion that he can do anything he wants in order to advance and protect liberty, supported by warrantless surveillance, incarceration without charge or trial, gratuitous torture, and execution thus fails for the same reasons articulated by Alexander Hamilton's assessment of the Jacobin Terror: "When conducted with magnanimity, justice, and humanity, [a struggle for liberty] ought to command the admiration of every friend to human nature. But if sullied by crimes and extravagances, it loses its respectability." (Chernow, 2004, p. 434).

\section{Domestic Effects of Absolutism}

If, then, absolutist governments exist solely to maintain power and control, then the country's citizens - and their rights and opinions - are at best an afterthought and at worst public nuisances, whether risking death on a battlefield 6,000 miles away or at home facing long-term imprisonment or execution. Moreover, they are always assumed to be potential troublemakers and therefore undeserving of traditional constitutional protections when they deviate from the government's official line. They become chattel, something to be controlled, traded, or eliminated as the occasion demands. ${ }^{8}$ This naturally requires a combination of subterfuge and plausible deniability by the executive when forced to admit the inconvenient. Treating society like $15^{\text {th }}$ century Florence, modern absolutists take a page from Machiavelli's 
playbook and operate according to the dictum that in the battle between truth and politics, the former must always lose.

This means that the executive, in this case President Bush, is able to stand before the American people and ask the question: Who are you going to believe, me or your own two eyes? He can call down God's blessing on Karla Faye Tucker while ordering her execution. ${ }^{9} \mathrm{He}$ can frame every domestic issue in national security terms, while the national poverty level increases yearly to the current embarrassing level of 12.7 per cent (Massing, 2005). ${ }^{10}$ $\mathrm{He}$ can brag about national preparedness while going mountain biking as the levees in New Orleans rupture during Hurricane Katrina, displacing most of the city's black population. ${ }^{11}$ And he can intentionally exploit the socioeconomic dichotomy that persists in the wealthiest country in the world, rewarding those who agree with his policies and punishing those who resist, up to and including executing those who fail most egregiously to fit into his pre-conceived idea of what a good (read obedient) citizen should be.

And where coercing the citizens' compliance is the primary goal of government, it is worth recalling the philosophy of George III (no relation) in a letter to his Prime Minister immediately prior to the Revolutionary War: "I am certain that any other conduct but compelling obedience would be ruinous.” (McCullough, 2005, p. 6).

\section{Imprisonment as an Absolutist Tool for Social Control}

According to a report by the National Criminal Justice Commission (NCJC), the incarceration rate in the United States is the highest in the world, with two per cent of the potential male work force now behind bars. In some areas, nearly half of young African-American men are in the criminal justice system, incarcerated at a rate six times higher than that of whites. The same report described "the largest and most frenetic correctional build-up of any country in the history of the world" (NCJC, 1996). Since 1980, the number of Americans in prisons and jails has tripled to over two million, resulting in a transfer of hundreds of billions of dollars from taxpayers' checking accounts to penal institutions and the ancillary businesses that service them, including the several million people who have come to depend on the prison industry for employment.

Sustaining the trend is the public's acquiescence to the government's exercise of unlimited power, even in the face of declining crime rates over the 
past 12 years. At the end of the millennium, the Bureau of Justice Statistics reported that America's prison population during the 1990s increased at an average of 7.7 per cent each year. Most experts point to longer sentences, mandatory sentences, and a drastic decrease in paroles as major factors in the explosion of the prison population. Those same experts, however, although remarking on the statistical evidence that indicates a racist, elitist, and absolutist system at work, refuse to draw the obvious conclusion that the world's highest rate of imprisonment functions as the principal tool for marginalizing and controlling the expanding number of citizens discarded in the pursuit of wealth and power by those making the decisions.

The government as a consequence insidiously plays on a cultural nationalism that in a time of war makes crime unpatriotic and reduces the ever increasing underclass to irrelevancy. According to the chorus of governmental rhetoric, street crimes, no less than the assaults of September 11, are direct assaults on the freedoms of all Americans. Domestic warfare thus commences, driven by the same casus belli as the government's imperial policies abroad: securing freedom and eliminating those who dare threaten it. This polarization is, of course, directly opposed to "a civic or pluralistic nationalism that shuns the divisiveness of narrow-gauge nationalism, that pays its respects to multiculturalism without abandoning the core concept of a common... experience" (Beplate, 2005, p.14).

America's citizens, through their unquestioned capitulation to presidential authority, buy the loyalty the government is selling, thereby underwriting a social catastrophe that works to their political and economic detriment and sends many of them into the criminal justice meat grinder, often in collusion with religious and social groups serving as shills for the government. In 2002, for example, of the 24 major metropolitan areas with the highest crime rates, 22 were in the South (Encarta Encyclopedia, "Federal Bureau of Investigation", 2005), where the President enjoys unqualified popularity and where capital punishment and fundamentalist religion work hand in hand to purge the body politic of undesirable elements, in effect removing potential critics of the government's policies, both domestic and foreign, disenfranchising them via felony convictions, and leaving them nowhere to turn for redress.

This lack of objection to executive fiat and the willingness to cooperate in the government's assault on fundamental liberties is hauntingly familiar. Chernow (2004) recalls Alexander Hamilton's stinging assessment of the 
country two years into the Revolutionary War, when he confronted the colony's initial submission to the abuses of George III. Their solipsistic preoccupation with their own comfort at the expense of fundamental rights, according to the primary author of The Federalist Papers, rendered them "fit only for the chain" (p. 125).

A supine Congress, the putative guardian of the people's rights and welfare, has encouraged this sort of absolutist overreach by abdicating its responsibility and ceding unconditional power to the executive. In passing the Patriot Act in 2001, a piece of legislation that went unread by every senator and representative prior to its passage, Congress gave the president authority to employ any means he deems appropriate to combat terror, loosely enough defined to encompass virtually any felony, including arrest and incarceration without formal charge. Out of that legislation came clandestine searches of libraries and book stores, warrantless domestic espionage, and the indefinite incarceration without trial of American citizens. In reality, the Patriot Act was merely the culmination of an orchestrated campaign by the government to arrogate the power to investigate and imprison more citizens for longer periods than at any other time in history.

\section{Execution as the Ultimate Absolutist Tool}

The United States has a long, sad history of killing its citizens, a pattern that continues in this post-industrial era. Following a brief respite from 1972 to 1977, executions resumed, primarily in the Bible Belt states of the South, again the region most supportive of the President. Until March 1, 2005, the United States was the only country in the world that permitted the execution of children under eighteen. That changed with Roper v. Simmons, 125 S.Ct. 1183 (2005), but even that vote in the Supreme Court was a narrow 5 to 4 opinion. Four of the nine justices thought it was morally and legally justifiable to execute a high school junior who could not buy a beer or vote.

Going back prior to 1988, the nation's highest court thought executing 15 year olds was permissible. Guided by "evolving standards of decency", the Court gradually increased the age at which citizens would be death eligible, raising the bar to 16 year olds ${ }^{12}$ before finally restricting execution to children 18 and older. Those evolving standards did not, however, extend 
past the campuses of secondary schools. As the killing of high school students gradually lost its cachet, a majority of the court in 1989 still agreed that executing the mentally disabled was perfectly in keeping with American jurisprudence. ${ }^{13}$ It was not until 2002 that the court, under serious international criticism, reversed itself and excluded the mentally disabled from the country's death machinery. ${ }^{14}$

At first glance, the practice of executing children and the mentally disabled, along with the usual array of condemned prisoners, might appear as simply bad luck on the part of the condemned. A closer reading of the application of capital sentences, however, discloses a more pernicious pattern at work: the executioner's axe in the United States falls disproportionately on the necks of the poor and minorities, or those deemed valueless by an absolutist power structure. As Justice Harry Blackmun observed in Callins v. Collins (1994), "race continues to play a major role in determining who shall live and who shall die". And once a death sentence has been imposed, no amount of reformation or redemption on the prisoner's part can stop it.

James Allridge was a former high school honour student and a small business owner in Texas when he and his brother were convicted of a homicide committed during a robbery of a convenience store. Both were black, and both were sentenced to death. This arrest was Allridge's only encounter with the criminal justice system (Gaucher, 2005). During his 17 years on death row, he became an accomplished self-taught artist and writer. His work appeared in several issues of this journal ${ }^{15}$ and was displayed in galleries across Europe and in the United States. He worked tirelessly from his cell for a variety of human rights causes and drew international support from across the social spectrum. His perpetual optimism was tempered by a realistic assessment of his precarious position, especially following the execution of his brother. He was comforted, however, by "his belief in the triumph of the human spirit and by his understanding that though he was responsible for a terrible mistake, he was also a redeemable human being and not industrial waste" (Gaucher, 2005, p. 103). He was executed on August 26, 2004.

Stanley Tookie Williams died in California's death house on December 13, 2005. ${ }^{16}$ Williams was a founder of the Crips street gang and convicted of four homicides, all committed during a string of armed robberies. His appeals exhausted, he petitioned Arnold Schwarzenegger, movie star and 
Governor of California, for clemency. Prior to his execution, Williams renounced gang membership, wrote a series of children's books warning of gang involvement, and was a regular nominee for the Nobel Peace Prize. All that mattered not a whit to the Governor. Schwarzenegger considered only Williams' convictions and the potential reactions to his clemency decision, especially significant given the support of the majority of Californians for capital punishment and the Governor's intent to run for re-election this year. As The Economist (2005, p. 29) put it, "Refusing clemency was, in political terms, a safer choice than granting it."

\section{Conclusion}

Opponents of capital punishment and long-term prison sentences view both through the lens of human rights and the proper limits of political power, something an absolutist government cannot admit. The 64 per cent of Americans who support executions, in contrast, tend to regard capital punishment and life sentences as issues of criminal justice policy, which is precisely what an absolutist government would wish. The American public thus supports the policies of absolutism, which in turn encourages the government to circumscribe their liberties even more, often justifying the measures by shifting the responsibility to the electorate.

When faced with a moral choice to execute or not, most elected officials lack the political courage to make the principled choice, preferring political expediency instead. They justify their decision by invoking "the people" who elected them and who overwhelmingly support the death penalty. It appears that the government of the United States has been successful in its campaign to convince a majority of the people that granting absolute power over its citizens, the power to take their lives as well as their freedom, is not only legal but proper.

Between 1977 and 2003, 7,061 people were sentenced to death in the United States, or roughly $25 \%$ of the population of the Yukon Territory. ${ }^{17}$ Of that number 875 men and 10 women were executed (Rigby, 2005). Even in face of 172 prisoners exonerated by DNA analysis, 14 of whom were on death row, the absolutist claim to power continues unapologetically. Completely absent is any sense of moral imperative. As Justice Antonin Scalia, the pre-eminent conservative voice of the Supreme Court, has said, "That [opposition to the death penalty] often refers to "intellectual, 
moral, and personal' perceptions, but never to the text and tradition of the Constitution. It is the latter rather than the former that ought to control." (Callins v. Collins, 1994).

The most recent addition to the same court is Samuel Alito, whose previous legal opinions have supported the right of police to shoot and kill an unarmed 15 year old fleeing from a $\$ 10$ burglary, the right of police to strip search a woman and her 11 year old daughter, even though they were not named in a search warrant, and blanket immunity for government officials who violate the rights of citizens (Turley, 2006). When asked if an innocent citizen had a constitutional right not to be executed, Judge Alito said that it depended on the procedural posture of his appeals (National Public Radio, "Morning", 2006). After his confirmation hearings in January 2006, Judge Alito took his place beside Justice Scalia, both physically and philosophically, which will doubtless permit an absolutist government to continue to spy on, imprison, and execute American citizens according to the desires of the executive.

George W. Bush has declared himself a born-again Christian and war president and has selected people for government positions who echo his ex cathedra philosophy, irrespective of their qualifications for the positions. But his political rhetoric applies to more than the consuming conflict in Iraq, his perceived strong point. Given his own participation in the deaths of 155 men and women when he was Governor of Texas and his Manichaean division of the entire world into realms of good and evil, given his re-election and the Congress' refusal to administer even the smallest corrective to his fiscal and social policies, the President now functions as an absolute ruler with the power to make war on anyone he chooses, even American citizens, whom he can imprison and even execute without restriction.

The current state of affairs in the United States thus confirms Clausewitz's (1883) observation that war is "nothing but a continuation of political intercourse, with a mixture of other means". Prisons and executions are those "other means" and therefore less about addressing criminal activity than political methods for controlling a restive population. The current government's laws and legal opinions, as extensions of its political thought, demonstrate that the war on crime and the war on drugs are not salutary efforts to cleanse the body politic but rather a thinly disguised, supererogated attempt to maintain an imperial status quo that relegates the majority of the population to a Hobbesian world of perpetual struggle. Since, as Duskin 
(2006) points out, "problems cannot be solved within the mindset that created them", the United States will continue to be the world's unenviable leader in imprisoning and killing its own people until philosophical and electoral changes produce a different mindset, one that ends the systematic assault on citizens whose primary offence is being poor and therefore irrelevant.

\section{ENDNOTES}

1 The government abruptly dropped its original charge in 2005 just as Padilla's case made its way to the Supreme Court. Padilla was convicted in August 2007 of terrorism conspiracy and material support of a terrorist organization and sentenced to 17 years.

2 Cf. Televangelist Pat Robertson's suggestion that the U.S. government assassinate Venezuelan President Hugo Chavez because of Chavez's opposition to the policies of the Bush Administration, or the Reverend Jerry Falwell's assertion that the terrorist attacks of September 11 were God's punishment visited on an apostate society.

3 The U.S. presidential election of 2000 was decided when the U.S. Supreme Court, by a 5 to 4 vote, halted the recount in Florida, where a substantial segment of the black (and Democratic) population was illegally disenfranchised.

4 Cf. George Bush's touted "ownership society" that is eroding the middle class's influence and prosperity through his regressive tax policies.

5 The U.S. is currently training Iraqi police units via a 10 week, 32 hour course in human rights and rule of law. Twenty-two police commandos were subsequently arrested as part of a death squad. See "Iraqi cops face abuse probe", USA Today, February 17, 2006, p. 7A.

6 A USA Today poll released on January 18, 2006, showed a solid majority of the public supporting Bush's authority to monitor their phone and e-mail conversations without warrant or oversight.

7 Immediately after September 11, Bush divided the world into two distinct spheres: "You're either with us or you're with the terrorists."

8 To illustrate, in 1993 the federal government launched an assault on the Branch Davidian compound in Waco, Texas, knowing that innocent women and children were present. The subsequent gunfight and fire killed all 80 people inside the compound. No government agent was ever disciplined.

9 Tucker, executed in February 1998 while Bush was Governor, was the first woman put to death in Texas since the Civil War. Bush subsequently ridiculed her clemency request in an interview with Vanity Fair magazine.

10 In New York alone, one in every five residents is now poor.

11 Even the President's mother is not immune, insisting when visiting the Astrodome following Katrina's devastation that the evacuees' plight "wasn't so bad" because they were all poor to begin with and were used to doing without.

12 Thompson v. Oklahoma. 108 S.Ct. 2687.

13 Penny v. Lnaugh, 109 S. Ct. 2934. 
14 Atkins v. Virginia, 122 S.Ct. 2242.

15 Journal of Prisoners on Prisons, Volumes 6:1,8, 11, 12.

16 See Nagelsen and Huckelbury, "Let Nature Take Its Course," Journal of Prisoners on Prisons, Volume 14:2 for a more extensive discussion of Williams' clemency application and execution.

17 Population as of 2001.

\section{REFERENCES}

Allen, G. (1895) British Barbarians.

Beplate, J. (2005) “Express or Exploit”, Times Literary Supplement, December 23 \& 30, 2005, p. 13-14.

Bodin, J. (1606) Six Books of the Republic.

Bureau of Justice Statistics (1998) "Prison and Jail Inmates at Midyear 1997", January 18, 1998. Washington, D.C.: United States Department of Justice.

Chernow, R. (2004) Alexander Hamilton. New York: Penguin Books.

Clausewitz, K. (1883) On War. New York: Penguin Books.

Cole, D. (2006) “Are We Safer?", The New York Review of Books, March 9, 2006, p. $15-$

18.

Duskin, A. (2006) "No-grow Areas", Times Literary Supplement, January 13, 2006, p. 7.

Encarta Encyclopedia (2005) “Absolutism”, "Federal Bureau of Investigation”, “James I".

Gaucher, R. (2005) "Victims-Both Side: A Tribute to James V. Allridge (1962-2004). Journal of Prisoners on Prisons, Volume 14:1, p. 101-107.

Grey, J. (2006) "The Mirage of Empire", The New York Review of Books, January 12, 2006, p. 4-8.

Hersch, S. (1974) The New York Times.

Jefferson, T. (1787) Letter to James Madison re Shays' Rebellion, January 30, 1787.

Massing, M. (2005) "The Press: The Enemy Within", The New York Review of Books, December 15, 2005, p. 36-44.

McCullough, D. (2005) 1776. New York: Simon \& Schuster.

National Criminal Justice Commission (1996) Imprisonment is not Effective. Washington, D.C.

National Public Radio (2006) “All Things Considered”, January 24, 2006, "Morning Edition”, January 13, 2006.

Rigby, M. (2005) "Report Details General Decline in Death Penalty Statistics for 2003", Prison Legal News, October, 2005, Paul Wright, editor.

Sustein, C. (2005) Laws of Fear. Cambridge: Cambridge University Press.

The Economist (2005) "Tookie v Arnold", December 17-23, 2005.

Turley, J. (2006) “Troubling times, a troubling nominee”, USA Today, p. 13A. 


\begin{abstract}
About the Author
Charles Huckelbury has been incarcerated for over 30 years and has hopes for release in 2008.

A regular contributor to the Journal of Prisoners on Prisons since 1997, Charles is an Associate Editor who co-edited Volume 14:2, 2006 with Susan Nagelsen. His essay, "Made in the U.S.A: A Post-Modern Critique" (JPP, Volume 15:1, 2006) won Second Prize in the Essay Category of the American P.E.N. Awards in 2005.

Charles Huckelbury (\#19320) can be contacted at the New Hampshire State Prison, P.O. Box 14, Concord, NH 03302, U.S.A.
\end{abstract}

